\title{
ANALISIS TINGKAT KERAWANAN BANJIR DI SUB DAS LAWE NATAM KABUPATEN ACEH TENGGARA
}

\author{
(Analysis Of Flood Vulnerability Levels In Sub DAS Lawe Natam District of Aceh Tenggara) \\ Ihsan Siddiq ${ }^{1}$, Hairul Basri ${ }^{*}$, Ashabul Anhar ${ }^{1}$ \\ Program Studi Kehutanan PSDKU USK Gayo Lues \\ Universitas Syiah Kuala \\ *Coressponding author: hairulbasri@unsyiah.ac.id
}

\begin{abstract}
Abstrak. Banjir merupakan fenomena alam yang biasa terjadi di suatu kawasan yang banyak dialiri oleh aliran sungai, sehingga banjir didefinisikan sebagai keberadaan air di suatu kawasan luas yang menutupi permukaan bumi. Kabupaten Aceh Tenggara dengan keadaan topografi yang berbukit dan bergunung sehingga banyak sungai di wilayah ini yang mempunyai aliran sungai yang cukup deras dan anak-anak sungai hingga ratusan jumlahnya. Dan Secara geografis Kabupaten Aceh Tenggara terletak antara 3055'23" - 4º16’37' Lintang Utara dan 96 43'23" 98¹0'32" Bujur Timur dengan topografi daerah bervariasi berbentuk suatu dataran yang dikelilingi oleh perbukitan dan pegunungan yang merupakan gugusan Bukit Barisan. Sebagian kawasannya merupakan daerah suaka alam Taman Nasional Gunung Leuser (TNGL).
\end{abstract}

Kata kunci: Kerawanan Banjir.

Abstract. Flooding is a natural phenomena in a region rich in streams. Thus, a flood is defined as the presence of water in a vast region that covers the earth's surface. Because of the rugged and mountainous topography of aceh, many of the rivers in the region have swift streams and tributaries of hundreds of them. And geographically, Southeast Aceh Regency is located between 3⒌'23 "$4^{\circ} 16^{\prime} 37^{\prime \prime}$ North Latitude and 96²43'23 "- 98¹0'32" East Longitude with varied regional topography in the form of a plain surrounded by hills and mountains which are the Bukit Barisan cluster. Part of the area is a nature reserve area of the Gunung Leuser National Park (TNGL).

Keywords: Flood Prone.

Jurnal Ilmiah Mahasiswa Pertanian, Vol 6, No 3, Agustus 2021 


\section{PENDAHULUAN}

Banjir merupakan fenomena alam yang biasa terjadi di suatu kawasan yang banyak dialiri oleh aliran sungai, sehingga banjir didefinisikan sebagai hadirnya air pada kawasan luas yang menutupi permukaan bumi. Aceh Tenggara merupakan Kabupaten di Provinsi Aceh yang terdapat kekayaan cagar alam nasional terbesar di Aceh, salah satunya adalah sumber daya air. Secara geografis Kabupaten Aceh Tenggara terletak antara 3'55'23" - 4¹6'37' Lintang Utara dan 96²3'23" - 98¹0’32" Bujur Timur dengan topografi daerah bervariasi berbentuk suatu dataran yang di kelilingi oleh perbukitan dan pegunungan yang merupakan gugusan Bukit Barisan. Sebagian kawasannya merupakan daerah suaka alam Taman Nasional Gunung Leuser (TNGL). Ketinggian tempat di Kabupaten Aceh Tenggara berkisar antara 50 mdpl-400 mdpl, dan memiliki luas wilayah seluas 4.231 .43 km² (RPI2-JM Bidang Cipta Karya Kabupaten Aceh Tenggara Tahun 2015-2019).

Buku Putih Sanitasi (BPS, 2011) Kabupaten Aceh Tenggara, menginformasikan keadaan topografi yang berbukit dan bergunung sehingga banyak sungai di wilayah ini yang memiliki aliran yang cukup deras, hidrologi mempunyai ciri sungai yang panjang seperti daerah aliran sungai (DAS) lawe alas dan anak-anak sungai hingga (Ratusan jumlahnya). Sungai tersebut berhulukan dari banyaknya gunung, diantaranya Gunung Leuser, Gunung Kemiri, Gunung Bendahara dan Gunung Perkison. Pada umumnya anak-anak sungai tersebut selalu berair disepanjang tahun yang mengakibatkan air sungai mengalir melalui sela-sela gunung sehingga pada musim penghujan daerah tersebut rentan terhadap bencana banjir. Sumber air utama berasal dari sungai Lawe Alas yang berhulukan di Kabupaten Gayo Lues dan terus mengaliri Kabupaten Aceh Tenggara dengan melintasi Kecamatan Ketambe, Darul Hasanah, Badar, Babussalam, Bambel, Babul Rahmah, dan Babul Makmur. Sungai Lawe Alas juga memiliki banyak anak-anak sungai diantaranya Sungai Lawe Bulan, Lawe Mamas, Lawe Sikap serta Sungai Lawe Natam sebagai objek penelitian.

Jurnal Ilmiah Mahasiswa Pertanian, Vol 6, No 3, Agustus 2021 
Informasi yang diperoleh dari lapangan menunjukan kondisi Sub DAS Lawe Natam saat ini mengalami degradasi dengan meningkatnya frekuensi banjir yang terjadi di Desa Natam, pada tahun 2018 dan 2019 banjir mengakibatkan kerugian bagi masyarakat setempat. Sub DAS Lawe Natam awalnya berperan besar dalam pemenuhan kebutuhan air masyarakat, baik sebagai sumber air bersih (untuk kebutuhan rumah tangga, seperti mandi, mencuci, dan air minum), serta pengairan persawahan, tambak dan lahan pertanian. Namun dalam beberapa tahun terakhir, banjir terjadi akibat dari konversi lahan hutan menjadi lahan pertanian seperti perkebunan masyarakat di sekitar kawasan Sub DAS Lawe Natam (Informasi Masyarakat).

\section{METODE PENELITIAN}

\section{Tempat dan Waktu Penelitian}

Penelitian ini telah dilaksanakan pada bulan Juli sampai September 2020. Lokasi penelitian berada di Sub DAS Lawe Natam, Kecamatan Badar, Kabupaten Aceh Tenggara. Secara geografis terletak di N 03³3'56.0 - E 09746'15.0.

\section{Alat dan Bahan Penelitian}

Alat yang digunakan dalam penelitian ini antara lain: GPS, Plastik Kantong, Pisau, HP, Pulpen, Buku Tulis, Komputer, Perangkat lunak Ms. Excel, dan Arc GIS 10.7. Bahan yang digunakan dalam penelitian terdiri dari data Curah Hujan, Data Shp Provinsi Aceh, Shp Kabupaten Aceh Tenggara, Shp Kelerengan, Shp Jenis Tanah. Shp Tutupan Lahan yang di peroleh dari dinas Pekerjaan Umum Kabupaten Aceh Tenggara serta masyarakat di Desa Natam.

\section{Pengumpulan Data Penelitian}

Dalam memperoleh informasi sesuai dengan penelitian pengumpulan data terbagi menjadi dua bagian yaitu: Data Primer hasil dari Observasi dan Wawancara ke lapangan dan Data Sekunder diperoleh dari lembaga atau instansi seperti Balai Wilayah Sungai Sumatera-I, 
Badan Meteorologi Klimatologi dan Geofisika (BMKG) Wilayah Staklim IV Indrapuri Aceh Besar, Bappeda Kabupaten Aceh Tenggara dan Dinas Pekerjaan Umum Kabupaten Aceh Tenggara.

\section{Pengolahan Data dan Analisis}

1. Siapkan alat dan data

Alat dan data yang tertera di atas disiapkan untuk menunjang kegiatan penelitian. Alat meliputi laptop dan software Arcgis 10.7.

\section{Overlay dan Proyeksi Peta}

Setelah selesai analisis atribut table, kemudian layers-layers disetiap parameter data di overlay untuk dijadikan dalam satu peta dengan langkah-langkah sebagai berikut: Geoprocessing, arctoolbox, spatial analyst tools, overlay, weighted overlay lalu masukan bobot pada setiap parameter peta. Layers hasil overlay yang sudah dirubah proyeksinya kemudian di lakukan proses perhitungan luas kawasan dengan berdasarkan tingkat kerawanan banjir dengan menggunakan calculate geometri.

\section{Analisis Kerawanan Banjir}

Nilai kerawanan suatu daerah terhadap banjir ditentukan dari total penjumlahan skor enam parameter yang berpengaruh terhadap banjir (Curah Hujan, Kelerengan, Ketinggian Lahan, Jenis Tanah, Penggunaan Lahan dan Buffer Sungai). Menurut Kingma (1991) nilai kerawanan ditentukan, dengan menggunakan persamaan sebagai berikut:

$$
K=\Sigma W i x X i
$$

Keterangan :

$\mathrm{K}$ = Nilai kerawanan

$\mathrm{Wi}=$ Bobot untuk parameter ke-i

$\mathrm{Xi}=$ Skor kelas parameter ke-i

Jurnal Ilmiah Mahasiswa Pertanian, Vol 6, No 3, Agustus 2021 


\section{HASIL DAN PEMBAHASAN}

\section{Penyebab Terjadinya Banjir}

Hasil analisis tingkat kerawanan banjir di Sub DAS Lawe Natam dianalisis berdasarkan 6 parameter yaitu curah hujan, kemiringan lereng, jenis tanah, penggunaan lahan, elevasi dan buffer sungai. Setiap parameter memiliki hubungan terhadap terjadinya banjir di Desa Natam. Hasil wawancara dan obsevasi yang telah dilakukan dilapangan menyimpulkan bahwa penyebab terjadinya banjir di Desa Natam, dikarenakan dari konversi lahan hutan menjadi lahan pertanian, ilegal logging dan curah hujan yang tinggi. Selain dari curah hujan dan penggunaan lahan, Sub DAS Lawe Natam mempunyai kondisi topografi dengan kelerengan yang sangat datar, datar dan landai. Kelas kelerengan sangat datar mendominasi wilayah tersebut dengan memiliki luas sebesar $12,07 \%$ serta datar memiliki luas 6,23\% serta landai memiliki luas sebesar 0,83\%. Kondisi wilayah yang berbukit dan tinggi di kawasan hulu DAS memiliki ketinggian 800-1600 Mdpl, sehingga arus aliran sungai ke bagian hilir (kawasan rendah) dengan ketinggian 200-400 Mdpl semakin cepat. kondisi ini diperburuk oleh terjadinya penyempitan (bottle neck) di area tengah Sub DAS karena terdapat bebatuan besar di sepanjang punggung-punggung badan DAS yang mengakibatkan tersumbatnya laju air.

Jenis tanah merupakan faktor yang turut mempengaruhi terjadinya banjir, di kawasan Sub DAS Lawe Natam. Terdapat enam jenis tanah yang tersebar di dalamnya yaitu, Podsolik coklat, Aluvial, Litosol, Podsolik Merah Kuning, Grumosol dan Regosol. Jenis tanah Podsolik coklat, aluvial, litosol tergabung kedalam satu kawasan yang memiliki luas 4,75\%. Serta Podsolik coklat, Podsolik merah kuning memiliki luas sebesar 10,86\%, kemudian Podsolik, Grumosol memiliki luas 2,07\% dan Regosol Aluvial dengan luas sebesar 0,68\%.Sementara itu, hasil analisis jarak suatu kawasan ke sungai mengacu pada kriteria lokasi yang umumnya pada dataran terkena banjir . Pengskoran dan kelas buffer sungai sudah di tentukan jaraknya mulai dari 0 - >100 meter dari area sungai, jarak 0-25 meter diberi skor 5. sedangkan jarak >100 diberi skor 1. Hal ini menunjukan

Jurnal Ilmiah Mahasiswa Pertanian, Vol 6, No 3, Agustus 2021 
bahwa semakin dekat kawasan dengan sungai maka semakin rentan terhadap bencana banjir. Berikut adalah analisis tingkat kerawanan banjir di Sub DAS Lawe Natam.

\subsubsection{Curah Hujan Sub DAS Lawe Natam}

Menurut data dari BMKG (Badan Meteorologi, Klimatologi dan Geofisika) Aceh Besar, Curah Hujan Kabupaten Aceh Tengara dapat dilihat pada Tabel 9.

\begin{tabular}{|l|l|l|l|l|l|l|l|l|l|l|l|l|l|}
\hline Tahun & Jan & Feb & Mar & Apr & Mei & Jun & Jul & Aug & Sep & Okt & Nov & Des & $\begin{array}{l}\text { Rata- } \\
\text { rata }\end{array}$ \\
\hline 2015 & 299 & 0.0 & 75 & 378 & -- & 138 & 189 & 466 & 340 & 580 & 943 & 776 & 4184 \\
\hline 2016 & 79 & 149 & 41 & 253 & 441 & 812 & 533 & 143 & 587 & 715 & 1634 & 765 & 6152 \\
\hline 2017 & -- & 269 & 367 & 853 & 135 & 127 & 12 & -- & 374 & 365 & 825 & -- & 3327 \\
\hline 2018 & 44 & 93 & 230 & 278 & 702 & 360 & 487 & 26 & 203 & 782 & 413 & 1062 & 4680 \\
\hline 2019 & 59 & 182 & 305 & 143 & 429 & 390 & 446 & 115 & 644 & 612 & 598 & 82 & 4005 \\
\hline
\end{tabular}

Sumber: (BMKG, 2020)

Rata-rata curah hujan pada Tahun 2015 mecapai $4148 \mathrm{~mm} /$ tahun, pada tahun 2016 mencapai 6152 mm/tahun, selanjutnya di tahun 2017 mencapai 3327 mm/tahun, serta pada tahun 2018 mencapai $4680 \mathrm{~mm} /$ tahun, dan ditahun 2019 mencapai 4005 mm/tahun.

\subsubsection{Kemiringan Lereng Sub DAS Lawe Natam}

Hasil analisis kelerengan Sub DAS Lawe Natam terdiri dari 3 kelas. Kelerengan sangat datar, datar dan landai. Adapun kelas kelas kemiringan lereng dapat di lihat pada Tabel 10.

\begin{tabular}{ccccc}
\hline No. & Kelas Kelerengan & Luas Kawasan & Persen $\%$ & Skor \\
\hline 1. & $0-2 \%$ & $1.207,16 \mathrm{Ha}$ & $12,00 \%$ & 5 \\
\hline 2. & $2-8 \%$ & $623,73 \mathrm{Ha}$ & $6,23 \%$ & 5 \\
\hline 3. & $8-15 \%$ & $8,37 \mathrm{Ha}$ & $0,83 \%$ & 4 \\
\hline
\end{tabular}

Sumber: Dinas Pekerjaan Umum

Tabel 10 menunjukan kelas kelerengan 0-2\% mendominasi kawasan Sub DAS memiliki luas sebesar 1.207,16 hektar. Kemudian kelerengan 2-8\% memiliki luas 623,73 hektar, dan kelerengan $8-15 \%$ memiliki luas sebesar 8,37 hektar.

Jurnal Ilmiah Mahasiswa Pertanian, Vol 6, No 3, Agustus 2021 


\subsubsection{Jenis Tanah Sub DAS Lawe Natam}

Hasil analisis Sub DAS Lawe Natam memiliki enam jenis tanah yang berbeda diantaranya adalah, Podsolik coklat, aluvial, litosol, podsolik merah kuning, grumosol dan regosol. Adapun kelas jenis tanah dapat di lihat pada Tabel 11.

\begin{tabular}{ccccc}
\hline No. & Jenis Tanah & Luas Kawasan & Persen \% & Skor \\
\hline 1. & Podsolik, Grumosol. & $207,93 \mathrm{Ha}$ & $2,07 \%$ & 4 \\
\hline 2. & Regosol, Aluvial. & $68,86 \mathrm{Ha}$ & $0,68 \%$ & 3 \\
\hline 3. & Podsolik Coklat, Aluvial, Litosol & $475,33 \mathrm{Ha}$ & $4,75 \%$ & 2 \\
\hline 4. & $\begin{array}{l}\text { Podsolik Coklat, Podsolik } \\
\text { Kuning. }\end{array}$ & $1086,77 \mathrm{Ha}$ & $10,86 \%$ & 1 \\
\hline
\end{tabular}

Sumber: Dinas Pekerjaan Umum

Tabel 11 menunjukkan kelas jenis tanah tersebar menjadi 4 bagian, jenis tanah Podsolik coklat, aluvial, litosol terdapat di dalam satu kawasan yang memiliki luas 475,33 Ha, selanjutnya podsolik coklat, podsolik merah kuning dengan luas 1086,77 Ha, serta podsolik, grumosol memiliki luas 207,93 Ha dan regosol, aluvial memiliki luas 68,86 Ha.

\subsubsection{Penggunaan Lahan Sub DAS Lawe Natam}

Tutupan Lahan di Sub Das Lawe Natam berdasarkan hasil analisis terdiri dari empat kelas, di antaranya hutan lahan kering sekunder, pemukiman, pertanian lahan kering, dan semak belukar. Adapun kelas penggunaan lahan Sub DAS Lawe Natam dapat dilihat pada Tabel 12.

\begin{tabular}{ccccc}
\hline No. & Kelas Penggunaan Lahan & Luas Kawasan & Persen \% & Skor \\
\hline 1. & Pemukiman & $15,68 \mathrm{Ha}$ & $0,15 \%$ & 4 \\
\hline 2. & Pertanian Lahan Kering & $57,6 \mathrm{Ha}$ & $0,57 \%$ & 3 \\
\hline 3. & Kebun Campuran-Semak Belukar & $635,52 \mathrm{Ha}$ & $6,35 \%$ & 2 \\
\hline 4. & Hutan Lahan kering Sekunder & $1130,09 \mathrm{Ha}$ & $11,30 \%$ & 1
\end{tabular}

Sumber: Dinas Pekerjaan Umum

Tabel 12 menginformasikan penggunaan lahan di Sub DAS Lawe Natam di dominasi oleh hutan lahan kering sekunder dengan mimiliki luas 1130,09 Ha, selanjutnya Kebun campuran dan 
Semak belukar dengan luas 635,52 Ha, kemudian Pertanian lahan kering memiliki luas 57,6 Ha dan Pemukiman dengan luas 15,68 Ha.

\subsubsection{Ketinggian Sub DAS Lawe Natam}

Ketinggian mempunyai pengaruh terhadap terjadinya banjir, didasarkan pada sifat air yang mengalir mengikuti gaya gravitasi dengan mengaliri dari daerah tinggi ke daerah rendah. Kawasan yang mempunyai ketinggian lebih tinggi berpotensi kecil untuk terjadi banjir, Sedangkan kawasan dengan ketinggian yang rendah berpotensi lebih besar terjadinya banjir. Kawasan Sub DAS Lawe Natam memiliki tiga kelas ketinggian, di hulu memiliki ketinggian 800-1600 Mdpl, kemudian di tengah kawasan memiliki ketinggian 400-800 Mdpl dan di hilir memiliki ketinggian 200-400 Mdpl. Adapun kelas ketinggian Sub DAS Lawe Natam dapat dilihat pada Tabel 13.

\begin{tabular}{ccccc}
\hline No. & Kelas Ketinggian & Luas Kawasan & Persen \% & Skor \\
\hline 1. & $200-400 \mathrm{Mdpl}$ & $414,6 \mathrm{Ha}$ & $4,14 \%$ & 5 \\
\hline 2. & $400-800 \mathrm{Mdpl}$ & $745,21 \mathrm{Ha}$ & $7,45 \%$ & 4 \\
\hline 3. & $800-1600 \mathrm{Mdpl}$ & $679,07 \mathrm{Ha}$ & $6,79 \%$ & 3
\end{tabular}

Sumber: Dinas Pekerjaan Umum

Tabel 13 Ketinggian kawasan Sub DAS Lawe Natam terbilang tinggi pada kawasan hulu dan relative rendah pada hilir nya, kawasan hulu memiliki luas 679, $07 \mathrm{Ha}$, kemudian pada tengah kawasan memiliki luas 745, $21 \mathrm{Ha}$ dan di hilir memiliki luas 414, $6 \mathrm{Ha}$.

\subsubsection{Buffer Sungai Sub DAS Lawe Natam}

Pemberian skor untuk buffer sungai dengan berdasarkan jarak dari suatu kawasan ke sungai. Kawasan yang berjarak 0-25 meter di beri skor 5. Sedangkan yang terjauh >100 meter di beri skor 1. Adapun pengskoran untuk kelas buffer sungai dapat di lihat pada Tabel 14.

Tabel 14. Buffer Sub DAS Lawe Natam

\begin{tabular}{ccc}
\hline No. & Kelas & Skor \\
\hline 1. & $0-25 \mathrm{~m}$ & 5 \\
\hline 2. & $25-50$ & 4 \\
\hline 3. & $50-75$ & 3 \\
\hline 4. & $75-100 \mathrm{~m}$ & 2 \\
\hline
\end{tabular}

Jurnal Ilmiah Mahasiswa Pertanian, Vol 6, No 3, Agustus 2021 


\subsection{Hasil Analisis Kerawanan Banjir}

Hasil analisis daerah rawan banjir di Sub DAS Lawe Natam didapatkan 2 kriteria kelas kerawanan banjir, dimana kelas tersebut adalah kelas Tidak Rawan dan Sangat Rawan. Kelas Tidak Rawan banjir memiliki luas sebesar 1.543,05 Hektar Sedangkan kelas Sangat Rawan banjir memiliki luas 292,04 Hektar. Berdasarkan hasil analisis tingkat kerawanan banjir Sub DAS Lawe Natam dapat dilihat pada Tabel 15.

\begin{tabular}{lcccc}
\hline No. & Nilai & Kelas Kerawanan Banjir & Luas Kawasan & Persen \% \\
\hline 1. & $2.20-3.02$ & Tidak Rawan & $1.543,05 \mathrm{Ha}$ & $84,08 \%$ \\
\hline 2. & $3.84,-4.65$ & Sangat Rawan & $292,04 \mathrm{Ha}$ & $15,91 \%$ \\
\hline 3. & Total & Kawasan Sub Das Lawe Natam & $1.835,09 \mathrm{Ha}$ & $100 \%$ \\
\hline
\end{tabular}

Penilaian kawasan kerawanan banjir di analisis berdasarkan enam parameter, zona Tidak Rawan Banjir dapat dikatakan wilayah yang aman atau daerah yang kurang rentan terhadap bencana banjir. Kawasan ini terletak pada dataran rendah dan tinggi pada kawasan

Sub DAS Lawe Natam memiliki ketinggian beragam dari ketinggian mencapai 200-1600 Mdpl, Tidak Rawan banjir merupakan kelas yang di dominasi oleh hutan lahan kering sekunder, kebun campuran serta semak belukar. Dengan kemiringan lereng datar dan landai dengan kelerengan antara 2-15\% persen. Jenis tanah pada kawasan ini adalah Podsolik, grumosol, Podsolik coklat merah kuning, podsolik coklat aluvial dan litosol dengan tekstur tanah gembur dan liat. Serta penggunaan lahannya jauh dari sungai dengan jarak >100 m sehingga kawasan tersebut terbilang tidak rawan terhadap terjadinya banjir.

Zona sangat rawan banjir ialah wilayah yang sangat rentan dan kritis terhadap bencana banjir, perbedaan kawasan rawan banjir dengan kawasan sangat rawan banjir ini terletak pada topografi Penggunaan Lahan, jenis tanah, kelerengan yang datar serta ketinggian wilayah, dimana sangat rawan banjir berada pada hilir DAS dengan ketinggian 200-600 Mdpl. Kelerengan yang sangat datar antara 0-8 \% dimana jika curah hujan yang tinggi dapat membuat genangan pada

Jurnal Ilmiah Mahasiswa Pertanian, Vol 6, No 3, Agustus 2021 
permukaan tanah, dan keadaan ini di perburuk oleh penggunaan lahan yang di dominasi oleh perkebunan, lahan pertanian serta pemukiman masyarakat desa natam yang memiliki skor 4. Selain itu jenis tanah pada kawasan ini Regosol, aluvial dan podsolik, grumosol dengan tekstur tanah halus berlempung dan kasar

halus berdebu. Daerah sangat rawan banjir ini pada tahun 2018-2019 telah terjadi bencana banjir yang mengakibatkan kerugian materil bagi masyarakat setempat, total 17 rumah warga terbawa arus banjir, jembatan penghubung kutacane-gayo lues hampir terputus, dan kawasan daerah aliran sungai (DAS) natam tertimbun material banjir.

Berdasarkan hasil analisis dari ke dua zona kerawanan banjir, perbandingan zonasi Tidak Rawan banjir yaitu sebesar 1.543,05 hektar atau 84,08\% dari total luas Sub DAS Lawe Natam, sedangkan zona Sangat rawan banjir memiliki luas sebesar 292,04 hektar atau 15,91\%. Adapun peta tingkat kerawanan banjir Sub DAS Lawe Natam dapat di lihat pada Gambar 9.

Jurnal Ilmiah Mahasiswa Pertanian, Vol 6, No 3, Agustus 2021 

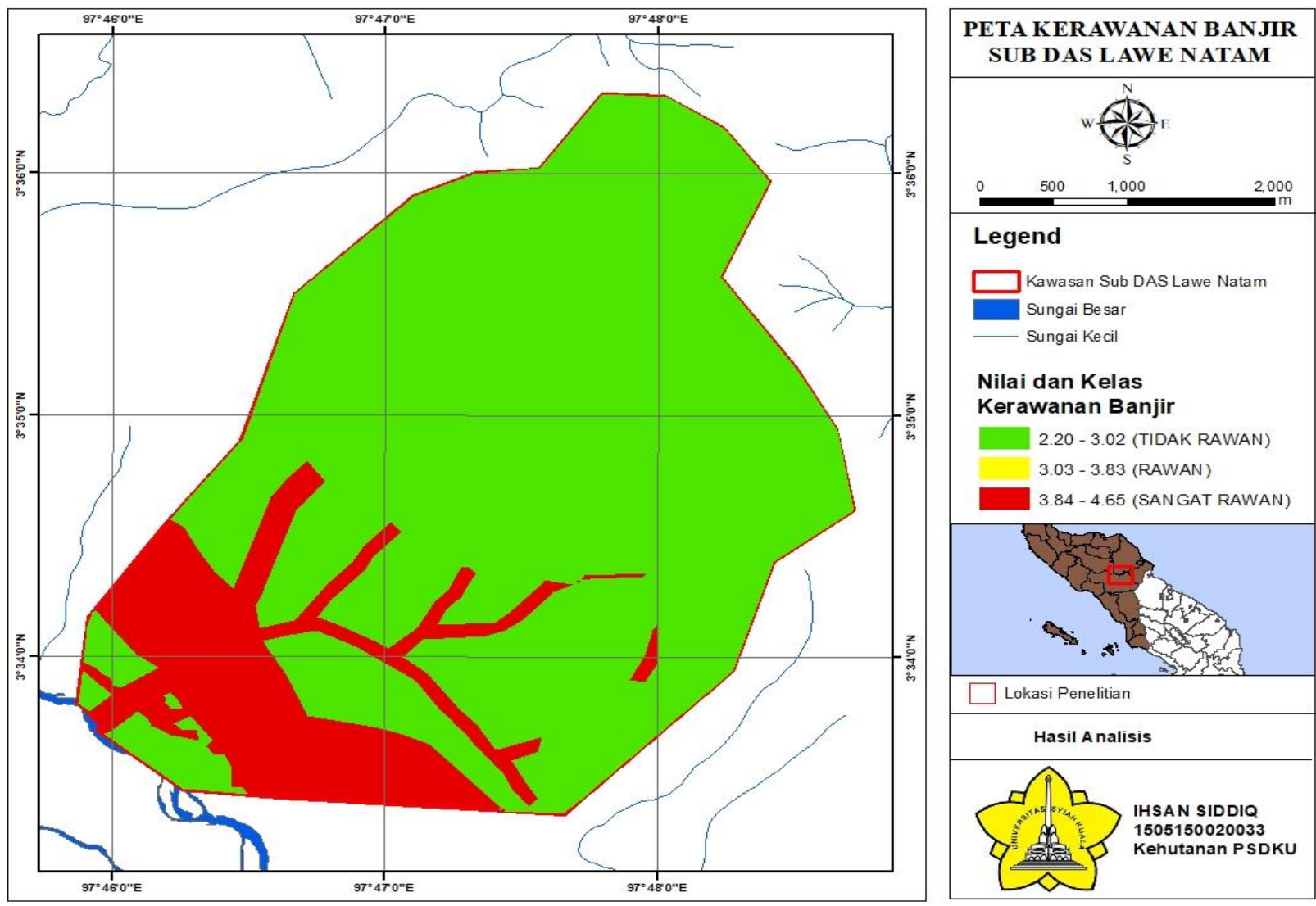

Gambar 9. Peta Kerawanan Banjir Sub DAS Lawe Natam 


\section{KESIMPULAN DAN SARAN}

\subsection{Kesimpulan}

Hasil analisis daerah rawan banjir di Sub DAS Lawe Natam didapatkan 2 kriteria kelas kerawanan banjir, dimana kelas tersebut adalah kelas Tidak Rawan dan Sangat Rawan. Kelas Tidak Rawan banjir memiliki luas sebesar 1.543,05 Hektar Sedangkan kelas Sangat Rawan banjir memiliki luas 292,04 Hektar. Perbandingan zonasi Tidak Rawan banjir yaitu sebesar 1.543,05 hektar atau 84,08\% dari total luas Sub DAS Lawe Natam, sedangkan zona Sangat Rawan banjir memiliki luas sebesar 292,04 hektar atau 15,91\%.

\subsection{Saran}

1. Perlu adanya penelitian lanjutan dan bekerja sama dengan institusi yang terkait untuk mengakuratkan alat, bahan serta data yang masih kekurangan.

2. Masyarakat yang melanggar aturan seperti ilegal loging agar ditindak dan diberikan hukuman oleh pemerintah daerah sesuai dengan peraturan yang berlaku agar kawasan Sub DAS Lawe Natam terhindar dari musibah bencana banjir.

3. Perlu di lakukan penghijauan kembali oleh dinas terkait dan masyarakat setempat agar kawasan Sub DAS Lawe Natam tetap terjaga kelestariannya

\section{DAFTAR PUSTAKA}

Buku Putih Sanitasi (BPS), Kabupaten Aceh Tenggara 2011.

RPI2-JM Bidang Cipta Karya Kabupaten Aceh Tenggara Tahun 2015-2019. Profil Kabupaten Aceh Tenggara.

Kingma, N.C., Westen, C.J.V., Alkema, D., Danem, M.C.J., dan Kerle, N. 1991. Multi-Hazard Risk Assessment. United Nation University.

Jurnal Ilmiah Mahasiswa Pertanian, Vol 6, No 3, Agustus 2021 